\title{
Language and Gender
}

\section{(preprint version)}

\author{
João Paulo Silvestre
}

In the field of language and gender, the term "stereotype" is often used to refer to prescriptions of, or unstated expectations of, behaviour. ${ }^{1}$ In this chapter, I intend to explore two sources of linguistic material that are traditionally referred to as examples of misogyny and gendered asymmetry: proverbs and dictionaries. With an analysis of a corpus of seventeenth-century proverbs, I shall try to demonstrate that the issue of gender is not predominant, and that references to women and men are often complementary.

Finally, I shall argue that our knowledge of the lexicon of Portuguese is limited, and that the number of derogatory words and phrases contained in dictionaries is not representative of a tendency towards misogyny in the language.

Sociolinguists study the relationship between gender and language in order to understand the social differentiation between men and women in particular communities. The forms and precise social significance of references to gender can vary considerably across cultures and over time. Language can be seen as a resource used by social actors to construct various kinds of masculinity and femininity so that they can align themselves with certain gender positions and differentiate themselves from others. The study of language and gender, then, tries to reveal how these two linguistic and social processes work.

Differences between the language of women and men, from a purely biological point of view, are not a relevant topic for research. Gender is just one of the many variables, others being, for example, age, class, ethnic and geographical origin, occupation, social role and status, and religious and political belief. Otherwise, statements about men's and women's linguistic behaviour tend to be probabilistic, asserting that there is a significant tendency for women to use a specific feature more than men, or vice versa. Usually, these statements portray men as the norm and women as the gender whose behaviour requires explanation.

1 Mary Talbot, "Gender Stereotypes: reproduction and challenge," in The Handbook of Language and Gender, ed. Janet Holmes and Miriam Meyerhoff (Oxford: Blackwell, 2003), 468-469. 
In a theoretical framework capable of analysing gender in a language, at least four categories of gender must be considered: grammatical, lexical, referential, and social. ${ }^{2}$

Grammatical gender is the morphosyntactic property of a noun which controls agreement between the noun's gender class and another element, which may be an article, adjective, pronoun or verbal form. These elements must be gender-variable, i.e. they must allow for a choice between at least two values, e.g. feminine and masculine (as in Portuguese and Spanish), or feminine, masculine, and neuter (as in German, Romanian and the Slavic languages).

Lexical gender constitutes part of the semantics of nouns. In Portuguese, a considerable number of personal nouns are lexically specified as carrying the semantic property [female] or [male]. This happens consistently in the field of kinship terms and animal names, but also in the case of professional terms ( cantora(f.) "female singer" vs. cantor (m.) "singer"), terms of address (Senhora Silva (f.) "Mrs Silva" vs. Senhor Silva (m.) "Mr Silva"), and personal names denoting female/male individuals. In these cases, there is a clear correspondence between a noun's grammatical gender class and its lexical specification as female or male. Such nouns may be classified as "gender-specific", in contrast to nouns such as habitante ("inhabitant") or paciente ("patient"), which are considered to be "gender-neutral" or "gender-indefinite". Of course, languages have lexical gender nouns irrespective of whether they also possess grammatical gender.

Referential gender links linguistic expressions to the non-linguistic world and identifies a referent as female, male, or gender-indefinite. Nouns like representante (f./m.) "representative" or artista (f./m.) "artist" may refer either to female or male individuals as well as "representatives" or "artists" in general. When viewed in isolation, they seem to be neutral with respect to lexical and grammatical gender. It is only within a specific context that the referential gender becomes evident. In other words, the satellite forms (in particular articles and determiners, which in Portuguese are almost always obligatory) carry gender markers that help identify the gender of the referent. Some Portuguese nouns, like those of other languages, show a mismatch between grammatical and referential gender.

Nouns have a social gender if the choice of associated words cannot be explained by grammatical, lexical or referential gender. Stereotypical conjectures about the social roles of women and men may be reflected in the lexicon

2 See Annette Endruschat, "Gender in Portuguese/' in Gender across Languages. The Linguistic representation of women and men, ed. Marlis Hellinger and Heiko Motschenbacher (Amsterdam: John Benjamins, 2015), 303-333. 
of a language, for example, by the list of professional and ceremonial terms. In societies where social and professional roles are divided between women and men, corresponding feminine and masculine professional terms are often not found. However, it is frequently the case that either a feminine or a masculine term does exist or is used. In Portugal, feminist emancipation in professional life has a long tradition, and such a strict division no longer exists. ${ }^{3}$ This situation is reflected in the lexicon, as new feminine occupational titles have been created and used. Compared to French ${ }^{4}$ and Spanish, ${ }^{5}$ the creation of such new terms seems more accepted. For example, in Portuguese, the form doutora (f.) "female doctor" is common, while in French, an equivalent form does not exist (there is only a double-gender noun docteur).
advogada (f.) "female lawyer" - advogado (m.) "lawyer"
médica (f.) "female doctor" - médico (m.) "doctor"
engenkeira (f.) "female engineer" - engenheiro (m.) "engineer"
cozinheira (f.) "female cook" - cozinheiro (m.) "cook"
antropóloga (f.) "female anthropologist" - antropólogo (m.) "anthropologist"
astrónomo (f.) "female astronomer" - astrónomo (m.) "astronomer"
veterinária $(\mathrm{f}$.$) "female veterinarian" - veterinário (\mathrm{m}$.$) "veterinarian"$
tecnólogo (f.) "female technologist" - tecnólogo "technologist" (m.)
geógrafa (f.) "female geographer" -geógrafo (m.) "geographer"
geóloga (f.) "female geologist" - geólogo (m.) "geologist"
técnica (f.) "female technician" - técnico (m.) "technician"

In principle, and irrespective of whether the language has grammatical gender, lexical or referential gender can be expressed symmetrically in any language, e.g., feminine/female terms can be derived from existing male/masculine terms (pintor, "painter" (m.) vs. pintora, "female painter"), and lexical gender nouns can be used in compounds in order to create morphologically symmetrical pairs, such as homem das limpezas ("cleaner", m.) vs. mulher das limpezas ("cleaning lady").

3 See Maria de Fátima Matias, "Língua e sexos (Sprache und Geschlechter)," in Lexikon der romanistischen Linguistik, vol. 6 Iss. 2, Galegisch, Portugiesisch, ed. Christian Schmitt, Michael Metzeltin and Gunther Holtus (Tubingen: Niemeyer, 1994), 332-339.

4 Elmar Schafroth, "Gender in French. Structural properties, incongruences and asymmetries," in Gender across Languages: The Linguistic representation of women and men. vol. 3, ed. Marlis Hellinger and Hadumod Buftmann (Amsterdam: John Benjamins, 2003), 87-117.

5 Kjaer Uwe Nissen, "Gender in Spanish. Tradition and innovation," in Gender across Languages: The Linguistic representation of women and men. vol. 3, ed. Marlis Hellinger and Hadumod Bußmann (Amsterdam: John Benjamins, 2003), 251-279. 
Frequently, the creation of female-specific nouns produces semantically asymmetrical pairs in which the female represents the lesser category, illustrating what Schulz has called semantic derogation. ${ }^{6}$

embaixador ("ambassador") vs. embaixatriz ("ambassador's wife")

costureiro ("fashion designer", m.) vs. costureira ("dress maker", f.)

The lexical gender of a personal noun corresponds in most cases to its grammatical gender. However, when we examine lexemes or idiomatic expressions in which lexical gender is involved, we find it is typical for female lexemes to be used in an ironic or negative sense, even though this is not the case for male lexemes. More specifically, we find female/male pairs in which the feminine form is used with a misogynistic connotation. For example, tipa (f.) denotes a "strange, ridiculous woman", while tipo (m.) "guy" is a much more positive term. Feminine nouns like gaja (f.) "young girl" or velha (f.) "old woman" are often used with a derisive connotation. Gajo (m.) means "guy" and velho (m.) "old man", without any negative connotations. Bruxa (f.) "witch" can refer to an old woman in a negative sense, while bruxo (m.) means "clairvoyant", also a more positive word.

There are also some examples of semantic derogation in occupational terms. Govemanta (f.) "housekeeper" is a woman employed in a household, while a governante (m.) "sovereign" denotes the ruler of a country. Secretária (f.) "female secretary" is an office assistant, while secretário $(\mathrm{m}$.) "male secretary" can describe a high-ranking position.

Sexist language can be described as a type of discriminatory language; it refers to language uses that disregard, underestimate, or offend (mainly) women. Linguistic expressions of such practices are female invisibility (o Homem, "mankind"), asymmetrical gender-marking ( polícia,"policeman") vs. mulher polícia, "police woman"), and stereotyping (mulheres de futebolistas, "footballers' wives").

Proverbs reflect socio-historical stereotypes and often preserve a long history of concepts and words. However, we cannot say that all Portuguese proverbs (or proverbs in the Portuguese language) were created to represent Portuguese society, as it is usually difficult to trace the origin and history of a proverb in a language. Many proverbs are identical in German and English, and in most of the Germanic, Romance, and Slavic languages, and were disseminated through linguistic contact.

6 Muriel Schulz, "The semantic derogation of woman/' in Language and Sex: Difference and Dominance, ed. Barrie Thorne and Nancy Henley (Rowley, MA: Newbury House, 1975), 64-75. 
Proverbs that have come down to us from Greek and Roman antiquity, passed on through the Latin language, were widely disseminated, and many became part of a rich Medieval Latin proverb tradition. More importantly, however, these texts were then translated into the many developing European languages. Latin proverbs were used in school translation exercises, and many of them entered the various languages through the oral tradition and were spread through the written and spoken word all over Europe. Their general use indicates a strong intellectual bond, without any specific national or ethnic references. And since they are noticeably identical in many languages, they are, and will continue to be, effective modes of metaphorical communication. In Portugal, the compilations of "sententiae" predate the first collections of proverbs. The most significant example is Amaro Roboredo's grammar book, which gathers around 1200 exemplary Latin phrases, translated into Portuguese and Castilian. The main themes are justice, morality and honour, without evident adaptations to the Portuguese social and cultural context, or references to the role of men and women. ${ }^{7}$

Unlike Latin sententiae, proverbs use concise and formulaic language so that they can be easily remembered and quickly integrated into oral discourse. They are used to convey everyday experiences and observations about society with a rhetorical intention. The written collections of proverbs are simply a more recent phase in the history of these expressions, which have certainly been part of the language since the pre-literary period. ${ }^{8}$

Proverbs were collected for centuries as valuable linguistic testimonies of cultural values and thoughts. The first anthology of "Portuguese" proverbs was compiled by Antonio Delicado (1610-?) and published in Lisbon in 1651 under the title Adagios Portugueses reduzidos a logares communs. ${ }^{9}$ This collection of proverbs, many of which are still in use, was the first formed from both literary and oral sources. Like most collections of proverbs, they are a set of moralistic expressions that convey crystallised norms of behaviour whose observance is fundamental for the maintenance of harmonious social order. ${ }^{10}$

7 Amaro de Roboredo, Porta de línguas ou modo muito accommodado para as entender publicado primeiro com a tradução Espanhola (Lisbon: Pedro Craesbeek, 1623).

8 Wolfgang Mieder, Proverbs: a handbook (Westport, cr and London: Greenwood Press, 2004).

9 António Delicado, Adagios portuguezes reduzidos a lugares communs pello lecenciado Antonio Delicado, Prior da Parrochial Igreja de Nossa Senhora da charidade, termo da cidade de Euora (Lisbon: Domingos Lopes Rosa, 1651).

10 Gonçalves studies the inclusion of proverbs in the first Portuguese dictionaries: Maria Filomena Gonçalves, „A 'fraseologia portuguesa' no Dictionarium Lusitanicolatinum (1611), de Agostinho Barbosa: breves apontamentos", Limite 7 (2013): 217-244. 
Interpersonal relationships and social roles are the subjects of most of these phrases. Albeit infrequently, since Delicado's compilation a few new proverbs have appeared, presumably inspired by the Portuguese imperial expansion and its effects on social organization and the expectations of individuals: "Quern nam tiuerque fazer, arme nauio, ou tome mother" I "He who has nothing with which to occupy his time, either prepares a ship to sail, or takes a wife."11 Here we can find unambiguous references to the perils of travel, the possibility of economic failure and warnings about ambition. There are also several mentions of slaves, not only as assets but also as figures one needs to interact with.

Nam pude passar o mar, sem da fortuna me queixar.

I could never take to sea without complaining about my lot.

Quem se nam quer auenturar, não passe o mar.

He who dares not take a risk, does not cross the seas.

Nem em mar tratar, nem em muytos fiar.

A wise man neither deals in the seas nor trusts in many.

Ao bom cauallo espora; \& ao bom escrauo açoute.

A spur makes a fine steed, just as a whip makes a fine slave.

Inda que somos Negros, gente somos, \& alma temos.

Black though we be, we are people, and we have a soul.

Boa fazenda he negros, se nam custassem dinheiro.

Niggers would be a profitable business if they didn't cost. ${ }^{12}$

A few years later, the Jesuit priest Bento Pereira (1605-1681), a teacher at the University of Évora, published a new compilation. This time, the proverbs were a supplement to a dictionary, as part of a method for improving writing skills through the study of the Latin translation of Portuguese sayings. This compilation, known as the Prosodia, ${ }^{13}$ was a companion for students and teachers,

11 This and the following quotes are from the electronic edition in Corpus Lexicográfico do Português. Centro de Linguística da Universidade de Lisboa - Universidade de Aveiro, accessed May 5,2019, http://clp.dlc.ua.pt.

12 Ibidem.

13 Bento Pereira, Florilégio dos modos de fallar, e adagios da lingoa portuguesa: dividido em duas partes, em a primeira das quaes se poem pella ordem do Alphabeto as Frases Portuguesas, a que correspondem as mais puras, Sc elegantes Latinas: na segunda se poem os principaes adagios Portugueses, com seu Latim proverbial correspondente. Pera se ajuntar a Prosodia, Sc Thesouro Português, como appendiz, ou complemento (Lisbon: Paulo Craesbeeck, 1661). 
providing exemplary sentences and common figures of speech. This volume influenced the cultural formation of political and religious elites during the first half of the seventeenth and eighteenth centuries. Pereira's selection of proverbs conveys, albeit not explicitly, a doctrinal message, describing a religious and political order. It provides a model of social behaviour and witty sayings and reflects the status and interests of those being educated, the moral values expected of them, and the Jesuit teaching goals. Political circumstances influenced the work, as can be seen in the vocabulary describing the experience of war, anguish, and difficulties encountered in everyday life. Keywords such as guerra, exército, batalha, inimigo, morrer, paz, medo, vencer are extremely frequent. ${ }^{14}$

Francisco Rolland (c. 1743-1814), the founder of Tipografia Rollandiana, edited the most extensive compilation in the eighteenth century. His collection was entitled Adagios, provérbios, rifãos e anexins da lingua portugueza tirados dos melhores authores nacionaes, and contained the proverbs of both Delicado and Pereira, since these authors' works were already out of print. ${ }^{15}$

The collections of proverbs which have been published since the seventeenth century show some thematic organisation, usually by keywords. This organisation is not sufficient to indicate the context in which the proverbs were used, nor their linguistic functions. However, it reveals the perception of a thematic division, which indirectly points to the functions that society assigns to each proverb. ${ }^{16}$

In the majority of proverbs, the gender of the subject is not relevant, or it is not mentioned. However, those that deal with women tend to follow specific patterns. According to Kerschen, "The overwhelming majority of proverbs that discuss women in a role deal with women as wives." ${ }^{17}$ Indeed, many compilations of proverbs, such as The Routledge Book of World Proverbs, show

14 See Teimo Verdelho, "Historiografia linguística e reforma do ensino. A propósito de três centenários: Manual Álvares, Bento Pereira e Marquês de Pombal/' Brigantia, Revista de Cultura 2, 4 (1982): 347-560.

15 Francisco Rolland, Adagios, provérbios, rifãos e anexins da lingua portugueza tirados dos melhores authores nacionaes, e recopilados por ordem alfabética porF. R. /. L. E. L. (Lisbon: Typografia Rollandiana, 1780).

16 Wolfgang Mieder, Op. Cit., xi.

17 Lois Kerschen, American Proverbs about Women: A Reference Guide (Westport, cT and London: Greenwood Press, 1998), 19. 
a substantial number of proverbs where the concept of "wife" constitutes the primary element in reference to women. ${ }^{18}$

Although some proverbs do praise and esteem women - notably mothers a substantial number can be interpreted as the products of overt sexism, satire and bitterness ${ }^{19}$ and, therefore, labelled as derogatory. They depict women as talkative, silly and disloyal.

The image of women transmitted by these proverbs can be either negative or positive, and is related to expectations about their social roles and behaviour. Central themes are marriage, households, children, the preparation of food, cooking, the Church, and widowhood, as well as beauty, tenderness and wisdom. As Marinovi points out, proverbs reflect the degree of attention paid to women in society, where they are seen as models in the family and in religious and social contexts. ${ }^{20}$ Negative traits for which women are often censured include chattering, anxiety, fragility and vengeance. There are also some Portuguese proverbs that transmit misogynistic images, such as clichés about stepmothers. ${ }^{21}$

Proverbs reinforce stereotypes; but when the compilations mentioned above are examined, some proverbs apparently contradict each other. The question of proverbs' meaning remains to be investigated by lexical and semantic studies. Linguists have tried to describe the semantic ambiguity of proverbs, which relates to the fact that speakers use them in various contexts with different functions. However, proverbs also act as analogies, and this adds to the difficulty of understanding their exact meaning in a particular piece of speech.

In order to understand the meaning of proverbs in specific contexts, it is important to keep in mind that these language units are mostly ambiguous, because their meaning depends on analogy with situations and events known to the speakers. Therefore, to comprehend the socio-cultural meaning of proverbs in oral and written communication, linguists also need to describe the strategies applied when users are choosing particular proverbial expressions.

Proverbs do not describe universal facts or truths; instead, they are valid only in certain situations. They seem contradictory when their social context

18 Jon Stone, The Routledge Book of World Proverbs (New York: Routledge, 2006).

19 B. Kochman-I laladvj, "(Negative) perception of women in proverbs across cultures of the changing world", Acta Facilitates Philosophicae Universitatis Prešoviensis 41(2012): 317 338.

20 Anamarija Marinovi, Provérbios e a mulher: O lugar da mulher nos provérbios portugueses e sérvios, accessed May 12, 2019, http://www.webartigos.com/artigos/proverbios-e-amulher-o-lugar-da-mulher-nos-proverbios-portugueses-e-servios/94755/\#ixzz2cRxuvhHI.

21 Annette Endruschat, "Gender in Portuguese," in Gender Across Languages. The Linguistic Representation of Women and Men, ed. Marlis Hellinger and Heiko Motschenbacher (Amsterdam: John Benjamins, 2015), 324. 
is ignored and when one attempts to analyse them in a literal sense. In context, however, proverbs function effectively as strategies to convey a social meaning. In fact, the meaning of any proverb is evident only after it has been put in context. Proverbs in everyday discourse are not contradictory at all, and they usually make perfect sense to the speaker and listener. Consequently, it is possible to distinguish between the theme of the proverb and the use of the proverb in a specific situation. Cultural historians are mainly interested in the first challenge, and they engage with it by studying and comparing proverbs that belong to a particular group or that can be grouped together under a theme, showing, for example, the traditional wisdom about gender issues over the centuries. $^{22}$

To better understand the extent to which gender issues are important in the Portuguese oral and literary tradition, we need to go back to the above-mentioned anthologies of proverbs published in the seventeenth and eighteenth centuries. Altogether, the three works have more than 10,000 proverbs, naturally with repetitions since each author uses the previous collection. If one seeks proverbs containing explicit references to mulher "woman, wife", homem "man", marido "husband" and filho, fdha "offspring" - the key words which mark gender as the subject of the proverb - one finds that they form only a small section of the corpus.

Table 5.1 Gender-related key words in the first collections of proverbs

Number of proverbs with an explicit reference to: Total number of proverbs women men husband offspring

\begin{tabular}{llcccc} 
Delicado, 1651 & 3720 & 114 & 106 & 27 & 104 \\
Pereira, 1661 & 1818 & 11 & 43 & 1 & 19 \\
Rolland 1780 & approx. 4900 & 225 & 271 & 49 & 220 \\
\hline
\end{tabular}

The most surprising aspect is that proverbs about women/wives are not the most frequent. In the compilations of Pereira and Delicado, there are even more proverbs in which the subject is the man. To exemplify the description of gender relations, I will use only proverbs from Delicado's compilation, citing 
the text of the digital edition from the Corpus Lexicográfico do Português. ${ }^{23}$ Without aiming for an exhaustive analysis of the whole corpus, it is possible to present some topics that stand out.

Some of the proverbs describe negative characteristics for both men and women in the same statement. They can be used in a speech to express the idea that women and men are different, and gender differences are represented as complementarities.

A homem ruivo, e a molher barbuda, de Longe os sauda.

Steer clear of the red-haired man and bearded lady.

Homem que fatia como molher, livreme Deos deite.

God save me from a man who speaks like a woman.

O homem he fogo, e a molher estopa; vem o Diabo assopra.

Man is the fire, woman is the straw. Onto them the Devil blows.

There are proverbs dedicated to exemplifying the negative characteristics of each sex. However, to describe womens flawed behaviour, there is often a comparison with the features of animals or objects. This rhetorical strategy does not occur when the subject is a man.

A molher he loba no escolher.

When it comes to choosing, the woman is a wolf.

A molher, e a galinha, com Sol recolhida.

Both woman and hen should be home by sunset.

A molher, e o vidro, sempre estam em perigo.

Woman and glass are always at risk.

A molher, e a cachorra, a que mais calla, he mais boa.

Of the woman and the bitch, the better is the quieter.

Beija o homem a mão, que quisera ver cortada.

A man will kiss the hand that he'd like to see cut off.

23 Corpus Lexicográfico do Português, Centro de Linguística da Universidade de Lisboa Universidade de Aveiro, accessed 12 May, 2019, http://clp.dlc.ua.pt. 
Ao homem farto as cerejas lhe amargam.

A man who's had his fill will be soured by cherries.

When the topic is marriage, both genders are usually represented as acting in a way that reinforces society's expectations regarding the behaviour of each of the spouses.

A molher, que dá no homem, na terra do Demo morre.

The woman who raises a hand to her husband will die in the land of the Devil.

O homem na praça, e a molher em casa.

A man's place is out and about, a woman's place is at home.

Pello marido vassoura, e pello marido senhora.

For the husband, she can be either a broom or a lady.

Still on the topic of marriage, the wife may be represented as manipulative or lying; but a close reading of the proverb shows that there is a binary structure. The woman's incorrect behaviour corresponds to a flaw in her husband's character.

Em casa de mesquinho, mais póde a molher, que o marido.

In the stingy man's house, the woman is more powerful than the husband.

Dor de cotovello, e dor de marido, ainda que doa logo he esquecido.

Resentment hurts, but like your husband's aches, is quickly forgotten.

Nam creais, marido, o que vedes, senam o que vos eu digo.

Husband, don't believe that which you see; believe only that which I tell you.

A dictionary definition places a word within a particular grammatical or material context (a text, for instance), thus constraining its usage and semantic perception. "If discourse is the text from which a dictionary is constructed, a dictionary becomes the text that, in turn, constructs discourse." 24 Recent language and gender research has inquired into how sexism, whether conscious

24 Paula Treichler, "From discourse to dictionary: how sexist meanings are authorized/" in Counterbalance: gendered perspectives for writing and language, ed. Carolyn Logan (Peterborough, Ont.: Broadview Press, 1997), 197-211. 
or unconscious, may enter dictionaries. The feature most often criticized is the inclusion of negative, stereotypical, or trivializing references to women. ${ }^{25}$

With regard to the Portuguese language, as described by lexicographers, a comparative analysis of dictionaries published in the early twentieth century and more recent works suggests that the question is far more complex. In fact, we can observe a decrease in the number of words that explicitly describe masculine behaviours or characteristics, making more evident the number of forms that refer exclusively to women. However, this change does not correspond to an actual semantic evolution, and the difference is due to lexicographers' practice of seeking a neutral description which assigns to both genders words with negative connotations.

The process becomes evident when we compare how three reference dictionaries include and describe epithets - adjectives or descriptive phrases that express a quality or characteristic of the person or thing mentioned (if positive, the epithet is eulogistic; if negative, it is derogatory).

TABLE 5.2 Dictionary entries for the word abóbora ("pumpkin") used in a derogatory sense

Figueiredo $1913^{26} \quad$ Bivar1948-1958 ${ }^{27} \quad$ Infopédia $2019^{28}$

$\begin{array}{lll}\text { Abóbora } & \text { Abóbora } & \text { Abóbora } \\ \text { Fig. Homem fraco, } & \text { ( s.f.mulher gorda) } & \text { Figurado, pejorativo mulher muito gorda } . \\ \text { indolente ou cobarde. } & \text { A fat woman } & \text { Figurative, derogatory: a very fat woman }\end{array}$

Mulher gorda.

A weak and indolent, or cowardly, man. A fat woman.

Figurado, coloquial pessoa indolente, sem iniciativa.

Figurative, colloquial: an indolent, spiritless person

The Novo Diccionário da Lingua Portuguesa, by Cândido de Figueiredo, was published in 1913. Figueiredo collected epithets used in various social and regional dialects. It is likely that speakers from Minho did not understand the meaning of epithets used by speakers from Alentejo. The same applies to

\footnotetext{
25 Paula Treichler, Op. Cit., 198.

26 António Cândido de Figueiredo, Novo diccionário da língua portuguesa (Porto: Typ. da Empr. Litter. e Typographyca, 1913).

27 Artur Bivar, Manuel Ferreira and Maria Ferreira, Dicionário geral e analógico da língua portuguesa (Porto: Ouro, 1948-1958).

28 Infopédia. Dicionário da Língua Portuguesa da Porto Editora, accessed May 12, 2019, http:// www.infopedia.pt/lingua-portuguesa/.
} 
adjectives used in Brazil and not in Portugal. Figueiredo's lexical corpus was the main source for subsequent dictionaries, such as Bivar's Dicionário geral e analógico da língua portuguesa (1948-1958).

The type of information we find in Bivar's dictionary describes a language stage in which the distinction of epithets for each genre was still perceptible by the speakers.

Algarivona. s.f. mulher muito alta. A very tall woman.

Arganaça. s.m. homem exageradamente alto. An extreme tall man.

Bernês. s.m. homem alto e deselegante. A tall, ungainly man.

Butelo. s.m. homem de grande estatura. A gigantic man.

Caravelão. s.f. mulher alta e magra. A tall, thin woman.

Filisteu. s.m. homem agigantado. A gigantic man.

Galalau. s.m. homem de estatura elevada. A tall man.

Giganta. s.f. mulher de alta estatura. A tall woman.

Girafa. s.f. mulher alta. A tall woman.

Goilão. s.m. homem alto e desajeitado. A tall, clumsy man.

Granada. s.m. homem alto e corpulento. A tall, burly man.

Manguarão. s.m. homem alto e magro. A tall, thin man.

Manguari. s.m. homem alto e esguio. A tall, thin man.

Orça. s.f. mulher alta e desajeitada. A tall, clumsy woman.

Padiola. s.m. homem alto e magro. A tall, thin man.

Recent dictionaries, such as the Infopedia, 2019, do not describe in such a detailed way the dialectal and sociolectal variety of the Portuguese language. However, they try to integrate as many words as possible, omitting relevant information about the social contexts of their use. A frequent strategy is to describe the epithets once applied to only one gender as if they could be used to characterize both men and women.

TABLE 5.3 Gender-bound derogatory terms

Figueiredo 1913

Infopeapedia 2019

Badalão m. Homem falador e desassisado. An unwise and talkative man.

Badalão. Indivíduo que fala muito e não tem juizo.

A person who talks a lot and acts unwisely. 
Badameco m. Ant. Homem sem importância. Badameco. Indivíduo sem importância. Outdated word. An insignificant man. An insiginifcant person.

Bandalho $m$. Homem coberto de trapos, desprezível. Pessoa desavergonhada, sem pundonor. Ant. Homem pretensioso e ridículo.

A despicable man covered in rags. A shameless, prideless person. Outdated word. A pretentious and ridiculous man. Bargante m. Homem de maus costumes, libertino.

A lustful man with bad habits.

Bebedolas m. Homem que se embriaga habitualmente.

A man who gets drunk often.

Bacalhau m. Prov. Beir. Mulher ordinária, tagarela e de costumes pouco exemplares. Provincialism from Beira Litoral. A chatty, common woman, with bad habits. Bacharela f. Pop. Mulher palradora, sabichona.

Slang. A talkative, know-it-all
Bandalho. Pessoa sem pundonor. A prideless person.

Bargante. Nome de 2 géneros. pessoa que age de uma forma desprezível; biltre. A person who acts in a despicable way, a soundrel.

Bebedolas. Nome de 2 géneros 2 números. coloquial pessoa que se embebeda com frequência. A person who gets drunk often.

Bacharela. Pejorativo. Mulher faladora, tagarela; mulher sabichona.

Derogative. A gossipy, talkative woman; a know-it-all.

The examples above reveal a tendency to rewrite lexical information when lexicographers do not have enough data on contexts. This principle does not apply to cases where change of usage has been proven to allow the adjective to describe both sexes. The examples below show the creation of masculine forms, commonly used in modern Portuguese. 


$\begin{array}{ll}\text { Badalhocaf. Prov. beir. Mulher suja e repugnante. } & \text { Badalhoco. } \\ \text { Provincialism from Beira Litoral. A dirty, digusting } & \text { Depreciativo: sujo, imundo, porco; } \\ \text { woman. } & \text { Depreciativo: obsceno; grosseiro. } \\ & \text { Derogatory: dirty, filthy; } \\ & \text { Derogatory: obscene; rude. } \\ \text { Bobaf. Bras. Mulher idiota ou aparvalhada. } & \text { Bobo. Parvo; estúpido. } \\ \text { Brazilian word. An idiotic or stupid woman. } & \text { Idiotic; stupid }\end{array}$

This brief survey has focused only on the lexicon; but it confirms the perception that the Portuguese language (or rather, the historical memory that we have of the Portuguese language) preserves information on the negative characteristics of various social groups. The samples do not offer the scope that would have been provided by evidence from several semantic domains, as they are limited to dictionaries and written authoritative sources. Linguists are aware that spoken language often progresses differently from the written record; but the type of written examples we have focused on - proverbs and epithets - are related to orality, as they represent formulaic structures.

Historical linguistics can illuminate the development of gender- and sex-related concepts by studying the process of their materialization, that is the new words and expressions related to them that became idioms and are now perceived as part of the language. Understanding how these processes of materialization were constructed through language in earlier times allows us to question the nature of modern identity labels. ${ }^{26}$

In the case of European Portuguese, we have sought to illustrate the process by which adjectives typically associated with men or women became epithets attributable to both sexes, often through the disregarding of their metaphorical origins.

Proverbs, in particular, exemplify linguistic strategies to derogate different social groups and confirm that, historically, women have been targets of the creative use of metaphor: women as animals, women as objects. If, over time, language changes, the same may be said of the metaphors speakers select to represent human characteristics, especially in the area of behavior. guistics to gender studies in general, and also in the framework in queer studies: Heiko Motschenbacher, Language, Gender and Sexual Identity. Poststructuralist Perspectives (Amsterdam/Philadelphia: John Benjamins), 29-31. 
